\title{
Death Ground
}

\author{
Dr Christos Michalakos \\ Abertay University \\ Dundee, Scotland \\ c.michalakos@abertay.ac.uk
}

\author{
Bernt Isak Waerstad \\ Norwegian University of Science and \\ Technology \\ Trondheim, Norway \\ bernt.i.waerstad@nmh.no
}

\begin{abstract}
Death Ground is a competitive musical installation-performance game for two players. The work is designed to provide the framework for the players/participants in which to perform game-mediated musical gestures against each-other. The main mechanic involves destroying the other player's avatar by outmaneuvering and using audio weapons and improvised musical actions against it. These weapons are spawned in an enclosed area during the performance and can be used by whoever is collects them first. There is a multitude of such power-ups, all of which have different properties, such as speed boost, additional damage, ground traps and so on. All of these weapons affect the sound and sonic textures that each of the avatars produce. Additionally, the players can use elements of the environment such as platforms, obstructions and elevation in order to gain competitive advantage, or position themselves strategically to access first the spawned power-ups.
\end{abstract}

All of the game's real-time parameters, such as player speed, health, types of power-ups collected, collisions and ground materials, are used to control musical parameters driving bespoke digital musical instruments.

Permission to make digital or hard copies of part or all of this work for personal or classroom use is granted without fee provided that copies are not made or distributed for profit or commercial advantage and that copies bear this notice and the full citation on the first page. Copyrights for third-party components of this work must be honored. For all other uses, contact the owner/author(s)

CHI'19 Extended Abstracts, May 4-9, 2019, Glasgow, Scotland, UK.

(c) 2019 Copyright is held by the author/owner(s).

ACM ISBN 978-1-4503-5971-9/19/05.

DOI: https://doi.org/10.1145/3290607.3313277 


\section{AUTHOR KEYWORDS}

Games; installation; improvisation; musical games; musical expression; NIME.
The instruments are designed to complement each-other sonically, and in combination with the realtime data control and offensive/defensive gestures, the result is a very tightly knit and dynamic audiovisual performance/installation experience. The game becomes the interface of the instruments as well as the performance's score. 